\title{
Extremely Preterm Infant
}

National Cancer Institute

\section{Source}

National Cancer Institute. Extremely Preterm Infant. NCI Thesaurus. Code C114939.

A newborn infant less than 28 weeks, 0 days gestational age. 